\section{SPECIES AND HABITAT CONSERVATION THROUGH SMALL LOCALLY RECOGNISED AND COMMUNITY MANAGED SPECIAL CONSERVATION SITES}

\author{
Hem Sagar Baral ${ }^{1}$, Bittu Sahgal ${ }^{2}$, Samiul Mohsanin ${ }^{3}$, Kuenga Namgay ${ }^{4}$ \& Aleem Ahmed Khan ${ }^{5}$ \\ ${ }^{1}$ Himalayan Nature, PO Box 10918, Lazimpat, Kathmandu, Nepal, \\ ${ }^{1}$ Currently at Zoological Society of London Nepal Office, Khumaltar, Lalitpur, Nepal \\ ${ }^{2}$ Sanctuary Asia, 602, Maker Chambers V, Nariman Point, Mumbai, Maharashtra 400021, India \\ ${ }^{3}$ Bangladesh bird club, House 11, Apt. 4B, Road 4, Bonani DOHS, Dhaka 1206, Bangladesh \\ ${ }^{4}$ Policy Planner, Ministry of Agriculture and Forests, Thimphu, Bhutan \\ ${ }^{4}$ currently School of Environmental Sciences, Charles Sturt University, Australia \\ ${ }^{5}$ Institute of Pure \& Applied Biology, Bahauddin Zakaria University, Multan 60800, Pakistan \\ ${ }^{1}$ hem.baral@gmail.com (corresponding author), ${ }^{2}$ bittusahgal@gmail.com, ${ }^{3}$ samiul.mohsanin@gmail.com, \\ ${ }^{4}$ kuenga007@gmail.com, ${ }^{5}$ aleembzu25@yahoo.com.au
}

ISSN

Online 0974-7907 Print 0974-7893

\begin{abstract}
Species' extinction rate is accelerating at an alarming rate all over the world. Conservation organizations are working day and night to halt this process by mapping areas for important biodiversity and highlighting these as priority areas for conservation. Most priority sites for conservation so far have been very large in area. Although some biodiversity is already lost, there is still much to conserve in the Himalayan region. Special Conservation Site (SCS) is an innovative concept for the conservation of small but important biodiversity congregation sites through a people participatory approach. Various guidelines and criteria are set as standard towards making this initiative readily accepted by all conservationists. By initiating this concept, we argue that SCS become a centre for education and awareness on the significance of biodiversity, mentor community-based conservation leaders, provide some income and ultimately add value to the larger landscape level initiatives and protected areas. SCS conservation should be an agenda for all.
\end{abstract}

Keywords: Congregation, conservation, people, species, stewardship.

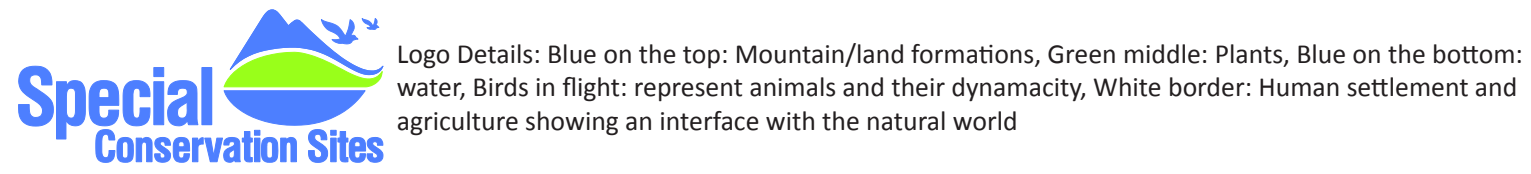

DOI: http://dx.doi.org/10.11609/JoTT.03792.5677-85

Editor: Anonymity requested.

Date of publication: 26 May 2014 (online \& print)

Manuscript details: Ms \# 03792 | Received 29 September 2013 | Final received 14 May 2014 | Finally accepted 15 May 2014

Citation: Baral, H.S., B. Sahgal, S. Mohsanin, K. Namgay \& A.A. Khan (2014). Species and habitat conservation through small locally recognised and community managed Special Conservation Sites. Journal of Threatened Taxa 6(5): 5677-5685; http://dx.doi.org/10.11609/JoTT.03792.5677-85

Copyright: (c) Baral et al. 2014. Creative Commons Attribution 4.0 International License. JoTT allows unrestricted use of this article in any medium, reproduction and distribution by providing adequate credit to the authors and the source of publication.

Funding: The project was initiated and funded by Himalayan Nature through its core funds. A pilot project in the lowland was supported through funds from WWF Nepal.

Competing Interest: The authors declare no competing interests.
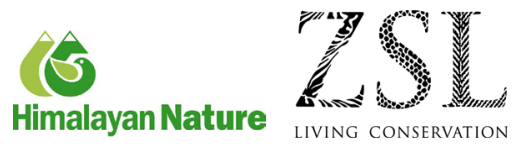

LIVING CONSERVATION

Author contribution: The coordination for paper writing was done by Hem Sagar Baral/Nepal with contributions from the co-authors from different countries.

Author Details: HEM SAGAR BARAL has a PhD in ecology from the University of Amsterdam, The Netherlands. He has been involved in wildlife conservation for over two decades and has held important positions for BirdLife Nepal, founded charities like Himalayan Nature and Nepalese Ornithological Union and very recently has taken up the position of Country Manager of Zoological Society of London for Nepal. BITTU SAHGAL is an environmental activist and writer, the founding editor of Sanctuary Asia, India's premier wildlife and ecology magazine. He is also a member of the National Board for Wildlife of the Ministry of Environment and Forests. He has been active in the field of wildlife conservation for more than four decades. SAMIUL MOHSANIN is a young ornithologist, wildlife conservationist and a well-known wildlife photographer in Bangladesh. He is an active member of Bangladesh bird club and has already authored several papers and books regarding wildlife of Bangladesh. KUENGA NAMGAY holds a PhD from Charles Sturt University, Australia and currently works as a Government Officer with Royal Government of Bhutan. Kuenga is a leading wildlife conservationist and think tank member of Bhutan. ALEEM AHMED KHAN is the first ornithological PhD in Pakistan and is one of the youngest professors in Pakistan. He has taught in many countries on taxonomy, wildlife and ecology. He is the founder of Ornithological Society of Pakistan - the leading bird conservation organisation in the country. He has authored numerous books and scientific papers.

Acknowledgements: We would like to thank Marcus Cotton, Dr. Paul Sterry, Prof. Karan Bahadur Shah, Carol Inskipp and Dr. Shalu Adhikari for their comments. Thanks are due to Kim Elliman, CEO of Open Space Institute, USA who provided seed money to pilot this program in Nepal through the WWF Nepal. A separate Nepal paper is due to come out after this paper has been produced describing the piloting of SCS in Nepal. We thank staff at Himalayan Nature, Dr. Hemanta Mishra, Jim Ottaway Jr., Brian Williams for their support. 


\section{INTRODUCTION}

We are living in a critical period of Earth's history in terms of the rapid changes in its environment. Many scientists have argued that as a consequence of human activities, the Earth is now entering the sixth mass extinction event in its four-billion-year history (and the only such event precipitated by a biotic agent) (Sackler 2007). Globally, we lose 5000 species per year as a result of urbanization, habitat loss and degradation, unsustainable harvesting of natural resources, climate change, and the spread of invasive species (Groom et al. 2006). Recent extinction rates are 100 to 1000 times their pre-human levels in well-known, but taxonomically diverse groups from widely different environments. Pimm et al. (1995) further state that if all species currently deemed threatened become extinct in the next century, the future extinction rates will accelerate at 10 times the recent rates. This means only a few threatened species will survive the century, but many species that are not currently in the threatened list will succumb. On the basis of mid-range climate-warming scenarios for 2050, a recent study ranging different continents predicted that $15-37 \%$ of species in certain area will be 'committed to extinction' (Thomas et al. 2004). The global scenario paints a gloomy picture for biodiversity and environment around us that we depend on.

It is shocking to think of a world without plants and animals, but species loss is just the tip of the iceberg. Conservation problems in our region are complex and often interlinked with poverty, illiteracy and lack of awareness. It is a dilemma that most biodiversity rich countries face today. They are very poor and conserving the natural heritage bestowed upon them appear to be a losing battle and an unsustainable work of art. Recent information suggests that the Himalaya which forms the northern border of the Indian subcontinent is one of the most biodiversity rich regions on the earth. But sadly many of the taxa found here have been listed as critically threatened revealing the imminent threats posed to the wildlife of the region (Chettri et al. 2010). The critically threatened species include Gharial Gavialis gangeticus, South Asian River Dolphin Platanista gangetica, Pygmy Hog Porcula salvania, several species of vultures, Bengal Florican Houbaropsis bengalensis, etc. We fear that the Himalayan region may have already lost species like Pink-headed Duck Aythya caryophyllacea, Himalayan Quail Ophrysia superciliosa, and many more are on the verge of extinction.

The biodiversity crisis is prompting scientific efforts on many fronts. Systematists are describing biodiversity and reconstructing the phylogeny of different life forms with regard to their evolutionary history and their relatedness. In recent years, as many as 353 new species have been described from mainly the eastern section of the Himalaya (Thomson \& Thomson 2009). Ecologists are mapping the distribution of biodiversity and global hotspots that merit special conservation attention (Sackler 2007). As a result, conservation organizations working at the international level have launched various programs aiming at safeguarding priority conservation sites and conserving the best examples of biological diversity. Some of these include Conservation International's biodiversity hotspots (Mittermeier et al. 2004) and key biodiversity areas (KBAs) (Eken et al. 2004; Langhammer et al. 2007), World Wildlife Fund's (WWF) 200 global eco-regions (Olson \& Dinerstein 1998), MacArthur Foundation's geographic priorities for conservation, BirdLife International's endemic bird areas (Stattersfield et al. 1998) and important bird areas (IBAs), Plantlife International's important plant areas (IPAs) (Hamilton \& Radford 2007), Alliance for Zero Extinction (AZE sites) and sites, IUCN-led important freshwater biodiversity areas (Foster et al. 2012), Zoological Society of London's Evolutionarily Distinct and Globally Endangered (EDGE) (species) zones (Safi et al. 2013), etc. In the Himalayan region, WWF together with government institutions and other regional stakeholders like International Centre for Integrated Mountain Development (ICIMOD) have launched-sacred Himalayan landscape, Terai arc landscape, Kailash sacred landscape initiative and the living Himalayas initiative which aim to preserve the landscape on a larger scale (WWF Nepal 2008; ICIMOD 2010). In the context of climate change, such greater landscape level conservation ideas, especially those including larger vertical gradients and multiple connecting corridors between protected areas, for example Chitwan Annapurna Landscape (CHAL) initiative in Nepal (Hariyo Ban Program 2013), are important and allow nature to adapt to the unprecedented changes brought about by the changing climate patterns including shift in species' distribution (Moritz et al. 2008). These are important initiatives and success of which depend on the support of community members on ground as well as the willingness of policy makers for developing policies at national and regional levels. These landscape level programs envision conservation of the entire landscape and corridor habitats. Important taxon areas like IBAs, IPAs, KBAs, Prime Butterfly Areas (Swaay \& Warren 2003), etc are addressed on a smaller scale at species level, 
nevertheless are extremely important and relatively very effective for conservation of representative biodiversity.

In an effort to save what is left of the Earth's biodiversity especially in the Himalayan region and south Asian region, Himalayan Nature has adopted a new conservation initiative, the Special Conservation Sites (SCS). Founded in 2000, Himalayan Nature is an international conservation research institute, initiating scientific research on Himalayan floral and faunal diversity and the broader environment (Himalayan Nature undated).

The primary aim of SCS initiative is to safeguard small but special natural sites close to human-dominated landscapes. These sites have usually large congregation of wildlife (animals and plants) whose protection does not clearly fall under anybody's jurisdiction. Many such sites combined will have a great role to play in conserving wild flora and fauna. The area of the SCS is much reduced when compared to initiatives by most national and global conservation forces (see Table 1). The SCS concept promotes nature conservation with stewardship from local people; 'small is beautiful and effective'!
In principle SCS is closely related with Community Conserved Area (Kothari 2006) but there are some fundamental differences. Community Conserved Areas (CCAs) are usually quite large and do not purposefully focus on concentration of biodiversity. These CCAs may have other values than wildlife and can also include, for e.g., conservation of watershed by a community for sustainable use of water resources. All SCS can be CCA but not the vice-versa. SCS also may seem similar to Sites of Special Scientific Interest (SSSI). SCS differs fundamentally with SSSI on being sometimes a site of heritage and social value given to wildlife, and may not be as high a scientific interest as SSSI. Satoyama Initiative (Takeuchi 2010) is very close and complementary to SCS as it works to conserve the entire landscape within which SCS could be a part. IUCN's sacred natural sites, India's community reserve and conservation reserve, UK's special areas of conservation, UK's sites of community importance are some of the other similar concept. SCS is a clearly visible location which could be pin-pointed on a map or landscape and where concerted efforts for conservation could be targeted (see Table 1).

According to the IUCN Category IV protected areas

Table 1. SCS and other conservation initiatives in the region with their main features

\begin{tabular}{|c|c|c|}
\hline $\begin{array}{l}\text { Existing Categories of } \\
\text { Conservation Initiatives }\end{array}$ & Important features & $\begin{array}{l}\text { Special Conservation Site (SCS) features- } \\
\text { different to other initiatives }\end{array}$ \\
\hline $\begin{array}{l}\text { Landscape Level } \\
\text { Conservation }\end{array}$ & $\begin{array}{l}\text { Very large, can spread to more than one country and identified based on broader } \\
\text { similarity of ecosystems (e.g., eastern Himalaya hotspot), suites of flora and fauna } \\
\text { inhabiting the area (Terai-duar grasslands eco-region), to increase trans-boundary } \\
\text { conservation among countries (SHL: sacred Himalayan landscape), identified } \\
\text { functional corridors for large animals (TAL: Terai arc landscape or TCL: tiger } \\
\text { conservation landscape), or to allow greater vertical corridors for animals and plants } \\
\text { in case of climate change effects (CHAL: Chitwan-Annpurna linkage), etc. These have } \\
\text { a holistic approach to cover the largest area possible. }\end{array}$ & $\begin{array}{l}\text { Very small, biodiversity focused and at a } \\
\text { pin-point locality }\end{array}$ \\
\hline Protected Areas (PAs) & $\begin{array}{l}\text { Large areas (usually }>1000 \mathrm{ha} \text { ) covering several ecosystems for the protection of } \\
\text { flora, fauna, natural scape and culture, usually one country, government recognized, } \\
\text { often no people living }\end{array}$ & $\begin{array}{l}\text { Small usually }<1000 \text { ha, mainly concerned } \\
\text { with flora and fauna, always in human- } \\
\text { dominated landscape }\end{array}$ \\
\hline Ramsar Sites & Only water body / related area is considered & $\begin{array}{l}\text { Mostly terrestrial but wetlands also } \\
\text { considered, some Ramsar sites could be SCS }\end{array}$ \\
\hline $\begin{array}{l}\text { Specific Taxon } \\
\text { Conservation (Important } \\
\text { Bird Area IBA, Important } \\
\text { Plant Area IPA, Prime } \\
\text { Butterfly Area PBA, etc.) }\end{array}$ & $\begin{array}{l}\text { Small to large areas, only one taxon focused (eg bird or butterfly or plant), small } \\
\text { areas closer to becoming SCS but not all, PAs often qualify, global perspective }\end{array}$ & $\begin{array}{l}\text { Wider in terms of taxa, all flora and fauna } \\
\text { with equal value, regional or national } \\
\text { perspective, PAs often do not qualify }\end{array}$ \\
\hline $\begin{array}{l}\text { Multiple Taxa } \\
\text { Conservation (Key } \\
\text { Biodiversity Area KBA) }\end{array}$ & $\begin{array}{l}\text { Wider in terms of inclusion of taxa but usually larger than SCS, PAs often qualify, } \\
\text { global perspective }\end{array}$ & $\begin{array}{l}\text { Usually smaller, regional or national } \\
\text { perspective, PAs as whole often do } \\
\text { not qualify because of their large size } \\
\text { and minimal opportunities for public } \\
\text { engagement in actual management }\end{array}$ \\
\hline $\begin{array}{l}\text { Community Conserved } \\
\text { Area (CCA) }\end{array}$ & $\begin{array}{l}\text { Always managed by community, usually larger than SCS, mostly only floral } \\
\text { component included, preservation could be for environmental services only, } \\
\text { could be sites that do not have much biodiversity and only to recognize cultural/ } \\
\text { traditional/religious importance }\end{array}$ & $\begin{array}{l}\text { Can also be privately managed area or on } \\
\text { private lands, biodiversity main component, } \\
\text { cultural importance not a criterion, usually } \\
\text { smaller than CCA, some CCA could qualify } \\
\text { as SCS }\end{array}$ \\
\hline $\begin{array}{l}\text { Sites of Special Scientific } \\
\text { Interest }\end{array}$ & Biodiversity, geology and scenic spots included, only in the UK, can be $>1000$ ha & $\begin{array}{l}\text { Biodiversity a requisite for geology or scenic } \\
\text { structures to be considered, smaller area }\end{array}$ \\
\hline Special Protection Areas & Birds considered, only in the UK & All form of biodiversity considered \\
\hline
\end{tabular}

(Sources: Ramsar Convention Secretariat 2013, Natural England 2014 and others listed under references 
aim to protect particular species or habitats and the management reflects this priority. Many Category IV protected areas will need regular, active interventions to address the requirements of particular species or to maintain habitats, but this is not a requirement of the category (IUCN 2013). SCS may best fit into this IUCN category although the usage of 'protected' may be slightly different here.

\section{What is a Special Conservation Site (SCS)?}

A SCS is a place that shelters one or many species considered to be important for conservation on a national or regional scale, and any flora and fauna of the area worthy of protection.

SCS can be a single tree or single animal using a particular habitat depending on the criteria chosen for selection. Any unique physical structure (such as caves, houses, monuments) that provides habitat for a particular species (or several species) could become a SCS. In other words, areas that have been identified as being of importance for roosting, breeding, feeding, wintering or the migration of a species or a group of species can be a SCS. More details are given in the guidelines for selecting a SCS (see Table 2).

\section{The need for SCS}

The need for SCS initiative has arisen for many reasons, mainly through the work done by Himalayan Nature. First and foremost, we value biodiversity inside protected areas but at the same time we appreciate nature that exists outside, especially the nature that prevails in human-dominated landscapes. All forms of biodiversity merit some sort of appreciation and care. The wealth of biodiversity that is preserved outside the strictly protected areas is usually dominated by common taxa compared to the biodiversity inside protected areas. Biodiversity inside protected areas is characterized by a few rarer and threatened species and many common species. The habitats outside the strictly protected areas are home to many common species and are important for maintaining the 'common' status of a species. In absence of habitats outside the strictly protected areas, many species that we commonly see around us would not have been so common. Secondly, by developing local stewardship in the local community, conservation education and awareness becomes more effective and targeted, and can operate in a more focused local patch. Awareness raised through these small sites contribute towards building a national conservation initiative and develop a broad public base to support important taxon areas, landscape level conservation approaches and larger regional geographic conservation initiatives. All conservation initiatives have recognized that some areas within larger landscapes can have higher concentrations

Table 2. Selection criteria for SCS

\begin{tabular}{|c|c|c|c|}
\hline Code & Criteria & Threshold (roost / rest / breed / feed regularly) & $\begin{array}{l}\text { Sources for Information/ } \\
\text { Verification }\end{array}$ \\
\hline $\mathrm{x} 1$ & $\begin{array}{l}\text { Globally threatened } \\
\text { taxon }\end{array}$ & 1 Pair or two animals & Global IUCN Red list \\
\hline $\mathrm{x} 2$ & $\begin{array}{l}\text { Nationally } \\
\text { Threatened Taxa }\end{array}$ & $\begin{array}{ll}\text { i) } & \text { CR } 1 \text { pair or two animals } \\
\text { ii) } & \text { EN } 2 \text { pairs or } 4 \text { animals } \\
\text { iii) } & \text { VU } 5 \text { pair or } 10 \text { animals }\end{array}$ & $\begin{array}{l}\text { Regional (e.g., South Asia)/ } \\
\text { Country Red Lists }\end{array}$ \\
\hline $\mathrm{x} 3$ & $\begin{array}{l}\text { Non-threatened } \\
\text { taxon* } \\
\text { (Concentration or } \\
\text { Congregation) }\end{array}$ & $\begin{array}{l}\text { i) } \begin{array}{l}\text { Breeding site }>100 \text { individuals or } 50 \text { pairs, currently used or was used until } \\
5 \text { years back }\end{array} \\
\begin{array}{ll}\text { ii) } & \text { Feeding site }>100 \text { individuals or } 50 \text { pairs regularly feeding in the area } \\
\text { iii) } & \text { Roost site }>100, \text { site is known for last five years } \\
\text { iv) } & \text { Stop-over: Used at least for two weeks or considered important as about } \\
100 \text { individuals or } 50 \text { pairs use the area annually for feeding }\end{array}\end{array}$ & $\begin{array}{l}\text { Country/State Lists } \\
\text { Ground truthing by Community- } \\
\text { based Organiations (CBOs), NGOs, } \\
\text { government bodies }\end{array}$ \\
\hline $\mathrm{X} 4$ & Natural Landscape & $\begin{array}{l}\text { Site holds unique assemblage of plants or scientifically important vegetation (listed in } \\
\text { IUCN global, or national red lists, national protection list, highly traded plant or fungi, } \\
\text { may have traditional cultural value and respect by local people and is uncommon to the } \\
\text { region) }\end{array}$ & $\begin{array}{l}\text { Local people's respect or expert's } \\
\text { statement, ground truthing by } \\
\text { experts }\end{array}$ \\
\hline X5 & $\begin{array}{l}\text { Artificial Structure } \\
\text { e. g. building, bridge, } \\
\text { chimney (this alone } \\
\text { is not a criterion) }\end{array}$ & Any structure containing any of the above, this alone is not a threshold for SCS & $\begin{array}{l}\text { Local people's respect or expert's } \\
\text { statement, ground truthing by } \\
\text { experts }\end{array}$ \\
\hline
\end{tabular}

$\mathrm{CR}=$ Critically Endangered; $\mathrm{EN}=$ Endangered; $\mathrm{VU}=$ Vulnerable

\# Criteria X1 to X3 are based on wild animal species whereas criterion X4 is based mainly on plant species.

* Conditions for population figures on different taxa apply. With relation to birds there are some super abundant birds at the moment for whom (non-threatened taxon) the thresholds suggested is more than 2500 individuals or 1250 pairs whichever fits. A tentative threshold numbers can be agreed at the national level for some of the super numerous animals/plants. A list of some of the super abundant taxa relating to higher vertebrates especially birds is given in Table 3 . For little known species of rodents/shrews these criteria may not apply. For herpetofauna and fish species the above given number are not applicable on non-threatened taxon and a local judgment should be implemented. For invertebrates, experts' opinion on both threatened and non-threatened taxa should be respected. In any case it is to be ensured that SCS declaration is logical for biodiversity importance, practical and sustainable from management point of view. 
Table 3. List of bird species considered to be superabundant for which different thresholds in terms of numbers are recommended

\begin{tabular}{|l|l|}
\hline English Name & Scientific Name \\
\hline Rock Pigeon & Columba livia \\
\hline Snow Pigeon & C. leuconota \\
\hline Parakeets & Psittacula spp. \\
\hline Barn Swallow & Hirundo rustica \\
\hline Red-rumped Swallow & H. striatus \\
\hline Martins & Riparia spp. \\
\hline Pipits and Wagtails & Anthus spp., Motacilla spp. \\
\hline Common Myna & Acridotheres tristis \\
\hline Jungle Myna & A. fuscus \\
\hline Bank Myna & A. ginginianus \\
\hline Asian Pied Starling & Sturnus contra \\
\hline House Sparrow & Passer domesticus \\
\hline Eurasian Tree Sparrow & P. montanus \\
\hline Red-billed Chough & Pyrrhocorax pyrrhocorax \\
\hline Yellow-billed Chough & P. graculus \\
\hline House Crow & Corvus splendens \\
\hline Large-billed Crow & C. macrorhynchus \\
\hline
\end{tabular}

of wildlife or unique biodiversity that are of exceptional value in the wider environmental context and such sites need special attention and recognition for their conservation. Thirdly, SCS are small enough units to be effectively managed by community members and local government. Ideally these sites do not require any international resources to manage, these sites are not like zoos but would act as such in a natural landscape. However, initial input of financial resources is vital to highlight their importance and to roll the SCS concept more widely in the region.

In lack of SCS initiative, we are rapidly losing valuable biodiversity that lie around our farmlands in rural and urban settings. We are also losing the typical agricultural landscape with sparse tree cover including large fig/ simal trees that provide shelter for resting and meeting area for local people. SCS is the only way forward to raise the profile of these valuable biodiversity sites and to raise awareness of local people and truly involve them in conservation.

Small scale conservation schemes such as SCS do not exist in our region at present. Protected areas are usually very large self-sustaining unit of ecosystem. Any existing system on protection of biodiversity in south Asia does not directly protect sites that are regarded to be SCS. Moreover, the SCS is almost invariably close to human settlements. In some protected areas, human settlements are allowed and SCS could be recognised within PAs in such cases. Whereas there are several protected areas in the region, where they do not allow any permanent human settlement. If PAs do not have human settlement, then it is assumed that all sites that qualify for SCS are fully taken care of by PA legislation. This is the main reason why the need to advocate SCS has arisen. Therefore in terms of their location, SCS are mainly outside the strictly protected areas but also within those protected areas where permanent human settlements exist. Promotion of small scale conservation initiative could be very effectively managed and in the long run helpful for larger conservation initiatives by bringing the much needed awareness and public support. It is anticipated that the SCS scheme will have multiple effects through changes in the mindset of people living nearby and in the state of biodiversity. In short, the SCS process will work towards the creation of a network of community stewardships and is a vital first step to sustainable conservation of the natural resources in human-dominated landscapes. A recent paper has highlighted the biodiversity and economic benefits that community managed areas can bring to local people (Sahgal 2012) and how SCS can benefit in similar ways should be explored.

\section{Special Conservation Sites selection guidelines}

Following are the general guidelines while designating a place as SCS:

1. Site is normally outside strictly protected areas although in the case of protected areas where human settlements feature as a part, the SCS can also be within a protected area. It can be as small as is deemed important for that place and species, although most sites are recommended to be well under 1000ha. Size criterion is based on practical reasons of managing the site through community stewardship and local government's support.

2. Site is known to be important for a number of years or used irregularly or regularly during different intervals of time by taxa under the various criteria given in the table below. The site is identified as vital to the survival of the species concerned. A site can qualify as an area used for roosting, resting, breeding and feeding by animals.

3. Site that sustains rare or unique flora and fauna. In some cases single mature tree species can qualify for this if the tree has unique value, e.g., very old, exceptional beauty, threatened nationally or regionally or globally, etc.

4. Site supporting or holding congregation/or 
concentration of a single or multiple species. The site should meet the criteria set for numbers as given in the table. Sometimes just a pair of a threatened taxon can be considered, depending upon their importance nationally, regionally or globally.

5. Once a site is qualified as an SCS, and for some reason it loses its value (criterion) afterwards, in such cases, the site should still be considered as SCS at least for five years.

These sites, carefully identified on the basis of the proposed guidelines, may include the best examples of the species' natural habitats, in terms of distinctively high numbers and densities, as well as their unique value to overall natural environment and humankind.

\section{Community Guardianship for SCS}

In many developing countries nature conservation is regarded as a role to be undertaken by certain individual conservationists, or organizations or government departments. In practice, the organizations themselves often consider that it's only them who can value and protect such sites. This attitude has misled conservation movement for a long time; conservation of nature is already known to be preserved through community stewardship and participatory management, but the approach is still unappreciated, untried and poorly valued.

Community Guardianship is key for the conservation of SCS. Developing community stewardship and local conservation leaders is a departure from the traditional concept. In community guardianship we carefully instill and instigate this approach, entrusting the role of conservation and management of SCS to local communities, members of which are on the site all the time. Local communities will own the SCS, so much so that the feeling of nature conservation, and activities targeted towards this end, will come from their inner soul. This program will groom motivated locals as future conservation leaders on whose shoulders lie the future of our wildlife.

Once a site is declared and listed as SCS the local government and the owners will be coordinating on the status of the biodiversity that first qualified the site as SCS. Any development work by the owners will have to be carried out in coordination with the local government authorities ensuring that the biodiversity is maintained. All these activities will be based on a SCS plan of action.

\section{Implementation of SCS}

Prior to being designated as a Special Conservation Site, a site will be assessed by a team led by a recognized agency. This will ensure that sites are chosen for their quality and value and the methodology is consistent with the guidelines/criteria proposed. The team evaluating may comprise members from the government ministries, planning commission, central development departments, civil society organisations (CSOs), nongovernmental organisations (NGOs), etc. It is assumed that in the long run, government(s) in the Himalayan region countries will adopt SCS as their own program with a legally defined category under the prevailing local acts, or conservation legislation and regulations at national level. As the concept is further developed and refined, country specific guidelines can be developed. This may need different level of discussion and details with concerned agencies, stakeholders and communities. As a regional body to promote cooperation, South Asian Association for Regional Cooperation (SAARC) could also take SCS as a basis for promoting not only biodiversity and environment but also for friendship and happiness among the people of the region. Bhutan has been promoting the innovative but very useful Gross National Happiness (GNH) concept, which is ultimately linked to the well being of humankind. GNH is the development philosophy in Bhutan that has environmental conservation as one of the four main pillars (Ura et al. 2012), a novel initiation of this country, which has been widely hailed by other nations.

To designate a site as an SCS, guidelines prepared in this paper and some timely modification may be sufficient. Recognized agencies like HN in Nepal or IUCN for the region may be regarded as having supporting role, advising the respective agencies on technical matters. The SCS idea could be replicated in any parts of the world if this concept is taken as a pragmatic approach for conserving biodiversity in the human-dominated landscape.

Ideally the lead ministry in any country should be the one that is responsible for the welfare and management of the villages/towns with technical back up from other ministries such as forestry, environment, agriculture and tourism etc. depending upon the structure of the administration. This is again a departure in thought process that is embedded in our minds for many years. It is important that biodiversity conservation becomes a minor stake also of other ministries that are currently seen only as developers. The forest or environment ministry that takes the lead in many countries for biodiversity conservation is therefore proposed in some places as a technical back up. The latter ministry will advocate and become concerned about biodiversity in any situation as their overarching goal. The involvement 
of conservation groups at the local level with the smallest independent unit of the government structure is crucial for its success. Some suggestions on who to take lead are given below with examples of some SCS in these countries where information is available to us. The implementing agency in the respective country can decide who should be the lead and who others to be the subsidiaries. CSOs or NGOs could help with financial and technical support for a successful conservation of the identified SCS.

\section{Suggested Lead Government Ministries for countries in and around Himalayan region}

Afghanistan: Urban Development Ministry as well as Rural Rehabilitation and Development Ministry could be the lead ministries with technical back up from National Environment Protection Agency.

Bangladesh: The Ministry of Environment and Forest, Ministry of Land, and Ministry of Fisheries and Livestock could be the main ministries with technical inputs from Bangladesh Forest Department, Department of Environment, and Department of Fisheries.

Bhutan: The lead ministry could be the Ministry of Agriculture and Forests (MoAF) with support from agencies with interest in biodiversity and environment conservation and preservation of national heritage sites such as National Environment Commission (NEC), Royal Society for Protection of Nature (RSPN), WWF Bhutan and Ministry of Home and Cultural Affairs (MoHCA).

China: The Ministry of Housing and Urban-Rural Development could be the lead ministry technically backed up by Ministry of Environmental Protection.

India: The lead ministries could be Ministry of Environment and Forests with Ministry for Urban and Rural Development in supporting role.

Myanmar: The lead ministry could be the Ministry of Forestry.

Nepal: The lead ministry could be the Ministry of Local Development with input in technical know-how from the Ministry of Forests and Soil Conservation. National Planning Commission may have a central role in planning, execution, and inventory of such sites, with monitoring and management responsibility to local level government.

Pakistan: The lead ministry could be the Ministry of Planning and Development with input in technical matters from the Ministry of Environment under the umbrella of, National Council for Conservation of Wildlife (NCCW) and by following the objectives of National Conservation Strategy (NCS).

Sri Lanka: The lead ministry could be the Local

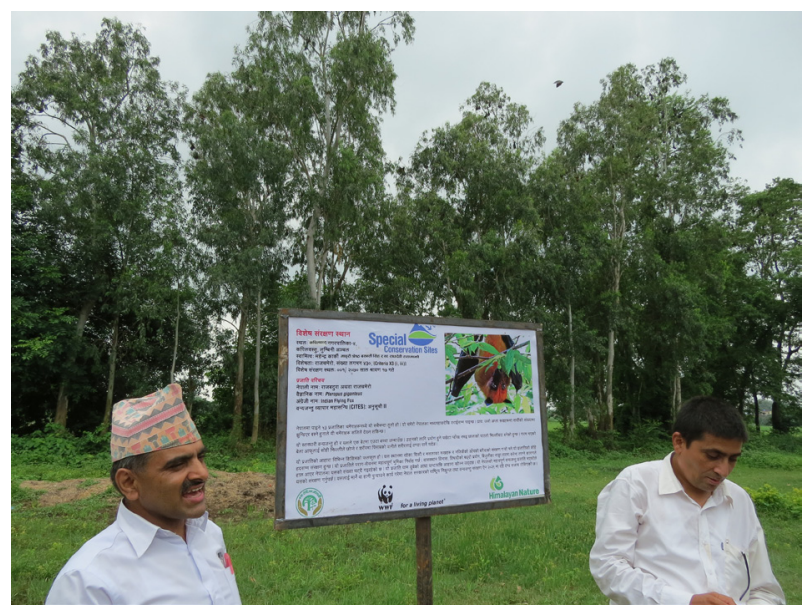

Image 1. The first SCS declared in Kapilvastu District, central Nepal, on the background roost trees of Indian Flying Fox and in the foreground, the SCS signage, Chief District Officer and Local Development Officer of the District, Government of Nepal providing information about SCS to local stakeholders and journalists.

Government and Provincial Councils with technical back up from the Ministry of Environment.

The SCS is already taking a momentum in Nepal and following are some examples of SCS from Nepal. An inventory of the sites in lowland districts is being compiled by Himalayan Nature (unpublished data):

(i) Flying Fox Roost in Kapilvastu Municipality, Lumbini Zone (Image 1).

Qualifying species: Indian Flying Fox Pteropus giganteus

Number (and Date of Count): 432 counted (July 2013)

National status: Least Concern

Area of spread: 1 ha

Ownership: Privately owned, three owners around the SCS.

(ii) Golchha House, Biratnagar

Qualifying species: Indian Flying Fox Pteropus giganteus

Number (and Date of Count): 2000 (2000)

National status: Least Concern

Area of spread: 1 ha

Ownership: Privately owned.

Golchha House, Biratnagar is located in the centre of Biratnagar Sub-Metropolitan City. Golchha family has a fruit orchard where trees like Mango, Litchi and some native timber trees are present. In this habitat, nearly 2000 Indian Flying Fox Pteropus giganteus roost regularly and have been roosting for the last 20 years. 
(iii) Rudrapur, Rupandehi

Qualifying species: Asian Openbill Anastomas oscitans

Number (and date of count): 500 nests (2008)

National status: Vulnerable

Area of spread: 1 ha

Ownership: Privately owned by Meena Shrechan

Rudrapur is located $7 \mathrm{~km}$ northwest of Lumbini, the birthplace of Lord Buddha. Within this village, on a private property of nearly $1 / 10^{\text {th }}$ of ha, two large Simal trees Bombax ceiba grow. Every year, for last 10 years, nearly 500 Asian Openbills Anastomas oscitans are breeding regularly.

\section{Inventory, Monitoring and Conservation of SCS}

The process of data gathering and archiving is important for the production of the baseline inventory. It offers the opportunity to involve wider community participation in the initial process and in doing so, creates ownership among local people and raises awareness.

Survey and monitoring should be conducted and all SCS should be documented to help support future conservation and management. A repeat survey annually or in a time frame considered suitable by the local authorities should provide insight on the state of the SCS. All SCS need active community participation and stewardship to ensure their long-term protection. Therefore, linking these sites to a responsible community or an individual leader is essential. In the future course of actions, the results in terms of biodiversity, economic and social gains should also be monitored. Annual monitoring of SCS is recommended by taking the support of local government and the local conservation leaders.

Depending on the nature of SCS and level of community involvement, local government bodies may conduct training on participatory inventorying and monitoring of the biodiversity of SCS. Good biodiversity preserved in the neighborhood means better quality of lives (measured through happiness, longevity, health issues etc). Therefore the SCS concept is vitally important for the quality of human life ultimately also benefiting wildlife.

\section{CONCLUSION}

SCS is a concept that emerges because of lack of a system in our region that values and recognises biodiversity found in the human-dominated landscapes. Such sites are already in existence in our neighborhood, we are simply advocating that such sites need to be conserved, appreciated and promoted. In fact a few sites are already given some level of local recognition. Our cultural civilization and age-old traditions are reflected in SCS, therefore any conscious citizen would need to be involved towards protecting such sites. These sites should be a pride for the particular locality as these act like open learning centers about biodiversity to all of us, and for our future generations. Many SCS combined protect a large amount of valuable biodiversity. This also helps the process of turning failed and marginal farms back to biodiversity rich status, along the edges of larger contiguous ecosystems that sequester carbon, thus offering marginalised communities the opportunity of taking a respected, global lead in tackling an issue -- climate change - that will ultimately have serious implications for all life on earth. Governments, non-governmental organisations, community based organisations, academic institutions, private companies, individuals should realize the value of such sites and start conserving SCS for our future generations.

\section{REFERENCES}

Chettri, N., E. Sharma, B. Shakya, R. Thapa, B. Bajracharya, K. Uddin, K.P. Oli \& D. Choudhury (2010). Biodiversity in the Eastern Himalayas: Status, trends and vulnerability to climate change; Climate change impact and vulnerability in the Eastern Himalayas. Technical report 2. Kathmandu: ICIMOD, 23Pp.

Eken, G., L. Bennun, T.M. Brooks, W. Darwall, L.D.C. Fishpool, M. Foster, D. Knox, P. Langhammer, P. Matiku, E. Radford, P. Salaman, W. Sechrest, M.L. Smith, S. Spector \& A. Tordoff (2004). Key biodiversity areas as site conservation targets. BioScience 54(12): 1110-1118.; http://dx.doi.org/10.1641/00063568(2004)054[1110:KBAASC]2.0.CO;2

Foster, M.N., T.M. Brooks, A. Cuttelod, N. de Silva, L.D.C. Fishpool, E.A. Radford \& S. Woodley (2012). The identification of sites of biodiversity conservation significance: progress with the application of a global standard. Journal of Threatened Taxa 4(8): 2733-2744; http://dx.doi.org/10.11609/JoTT.o3079.2733-44

Groom, M.J. (2006). Threats to biodiversity, pp. 63-109. In: Groom, M.J., G.K. Meffe \& C.R. Carroll (eds.). Principles of Conservation Biology. Sinauer Associates, Inc, Masschusetts, xix+779pp.

Hamilton, A.C. \& E.A. Radford (2007). Identification and Conservation of Important Plant Areas for Medicinal Plants in the Himalaya. UK: Plantlife International and Kathmandu: Ethnobotanical Society of Nepal, 44Pp.

Hariyo Ban Program (2013). Chitwan Annapurna Landscape: A Rapid Assessment. WWF Nepal Program, Kathmandu.

Himalayan Nature (undated). Conserving Biodiversity for People. A brochure, 12pp.

ICIMOD (2010). Kailash Sacred Landscape Conservation Initiative. International Centre for Integrated Mountain Development. Kathmandu, Nepal, 4pp.

IUCN (2013). http://www.iucn.org/about/work/programmes/gpap home/gpap_quality/gpap_pacategories/ Downloaded on 14 May 2013.

Kothari, A. (2006). Community conserved areas: towards ecological and livelihood security. Parks 16(1): 3-13.

Langhammer, P.F., M.I. Bakarr, L.A. Bennun, T.M. Brooks, R.P. Clay, W. Darwall, N. de Silva, G.J. Edgar, G. Eken, L.D.C. Fishpool, G.A.B. 
Fonseca, M.N. Foster da, D.H. Knox, P. Matiku, E.A. Radford, A.S.L. Rodrigues, P. Salaman, W. Sechrest \& A.W. Tordoff (2007). Identification and Gap Analysis of Key Biodiversity Areas: Targets for Comprehensive Protected Area Systems. IUCN, Gland, Switzerland, $116 \mathrm{pp}$

Mittermeier, R.A., P. Robles-Gil, M. Hoffmann, J. Pilgrim, T. Brooks, C.G. Mittermeier, J. Lamoreaux \& G.A.B. da Fonseca (eds.) (2004). Hotspots Revisited: Earth's Biologically Richest and Most Endangered Terrestrial Ecoregions. CEMEX, Monterrey Conservation International, Washington D.C.; and Agrupación Sierra Madre, Mexico.

Moritz, C., J.L. Patton, C.J. Conroy, J.L. Parra, G.C. White \& S.R. Beissinger (2008). Impact of a century of climate change on smallmammal communities in Yosemite National Park, USA. Science 322(5899): 261-264; http://dx.doi.org/10.1126/science.1163428

Natural England (2014). Designations. http://www.naturalengland. org.uk/ourwork/conservation/designations/default.aspx Accessed on 4 May 2014.

Pimm, S.L., G.J. Russell, J.L. Gittleman \& T.M. Brooks (1995). The future of biodiversity. Science 269(5222): 347-350.

Ramsar Convention Secretariat (2013). The Ramsar Convention Manual: A Guide to the Convention on Wetlands (Ramsar, Iran, 1971) - 6th Edition. Ramsar Convention Secretariat, Gland, Switzerland, 109pp.

Sackler, A.M. (2007). In the Light of Evolution II: Biodiversity and Extinction. A colloquium held between 6-8 December, 2007, at the Arnold and Mabel Beckman Center of the National Academies of Sciences and Engineering in Irvine, CA.
Safi, K., K. Armour-Marshall, J.E.M. Baillie \& N.J.B. Isaac (2013). Global patterns of evolutionary distinct and globally endangered amphibians and mammals. PLOS ONE 8(5): e63582; http://dx.doi. org/10.1371/journal.pone.0063582

Sahgal, B. (2012). Cutting edge conservation. Sanctuary Asia 32(4): 102.

Stattersfield, A.J., M.J. Crosby, A.J. Long \& D.C. Wege (1998). Endemic Bird Areas of the World: Priorities for Biodiversity Conservation. BirdLife International, Cambridge, UK, 846pp.

Swaay, C.V. \& M. Warren (2003). Prime Butterfly Areas in Europe: Priority Sites for Conservation. Wageningen, The Netherlands: National Reference Centre for Agriculture, Nature and Fisheries. Ministry of Agriculture, Nature Management and Fisheries, 6pp.

Takeuchi, K. (2010). Rebuilding the relationship between people and nature: the Satoyama Initiative. Ecol Res 25: 891-897; http://dx.doi. org/10.1007/s11284-010-0745-8

Thomas, C.D., L. Cameron, R.E. Green, M. Bakkenes, L.J. Beaumont, Y.C. Collingham, B.F.N. Erasmus, M.F. de Siqueira, A. Grainger, L. Hannah, L. Hughes, B. Huntley, A.S. van Jaarsveld, G.F. Midgley, L. Miles, M.A. Ortega-Huerta, A.T. Peterson, O.L. Phillips \& S.E. Williams (2004). Extinction risk from climate change. Nature 427: 145-148; http://dx.doi.org/10.1038/nature02121

Thomson, C. \& T. Thomson (2009). Eastern Himalayas Where Worlds Collide. Thimphu, New Delhi, and Kathmandu: WWF, 28pp.

Ura, K., S. Alkire \& T. Zangmo (2012). GNH and the GNH Index. Retrieved from http://www.ophi.org.uk/wp-content/uploads/Uraet-al-Bhutan-Happiness-Chapter.pdf

WWF Nepal (2008). WWF Nepal Annual Report 2007-2008. Kathmandu, Nepal, vii+33pp. 